"The country still faces a series of domestic and external challenges that remain significant hurdles on the path to great power status."

\title{
India Held Back
}

\author{
SUMIT GANGULY
}

$\mathrm{H}$ ow is India faring in its rise as a significant economic and diplomatic player in Asia and beyond? Certainly, reasons for optimism exist. In the late 1980s the country's economy began to exceed its traditionally anemic "Hindu rate of growth" (a joke introduced by the late Indian economist, Raj Krishna, based on the economic concept of a "secular rate of growth"). Also, at the end of the cold war, India dispensed with its hoary commitment to nonalignment and its reflexive anti-Americanism. Finally, India disproved the polemical claim that, despite the country's democracy and federalism, it would prove unable to contain ethnic separatism of the sort that was unleashed by the collapse of the poly-ethnic Soviet Union and Yugoslavia.

India may yet emerge as a major power in Asia, with its influence extending well beyond its immediate vicinity. However, as a quick survey of events in the past year demonstrates, the country still faces a series of domestic and external challenges that remain significant hurdles on the path to great power status. These challenges include an economic conundrum, fractious internal politics, growing governance problems, and difficulties both in tackling indigenous Islamic extremism and in improving relations with India's ever-nettlesome neighbor, Pakistan.

While India has so far defied all doomsday scenarios constructed for it, its ability to deal with and indeed overcome its structural shortcomings ultimately will determine whether it can transcend its role in South Asia and emerge as a global power of some consequence.

\section{PeRSISTENT POVERTY}

In late August 2008, the World Bank released a major study that provided some rather disturbing

Sumit GANGULY, a Current History contributing editor, is a professor of political science and director of research at the Center on American and Global Security at Indiana University. evidence about the persistence of absolute poverty in India. According to the report, the segment of the population living on less than $\$ 1.25$ a day in all of South Asia had fallen from 60 percent to 40 percent between 1981 and 2005. More specifically, within India, it had declined from 60 percent to 42 percent during the same period. Yet, despite this progress, the study concluded that well over 400 million Indians were still eking out a living on less than $\$ 1.25$ a day in 2005 .

Beyond this startling revelation, the Indian economy has been reeling this year from two important exogenous shocks-the high prices of both petroleum and food on the global market. Petroleum products' dramatic rise in cost has dealt a particularly hard blow to India's economy. India's gross domestic product, after achieving 9 percent growth in 2007, will grow by about 7 percent at best this year, according to even the most optimistic forecasts. The greatest concern to most Indian policy makers, however, is not slowing growth but a sharp spike in inflation-which now hovers close to 13 percent.

These statistics should give the Indian government pause, especially because they represent such a contrast to the bulk of the past decade, when the country has managed to grow by over 8 percent annually. Given that India has steadily registered high growth rates since it embarked on economic liberalization following an unprecedented fiscal crisis in 1991, the country's failure to make a greater dent in endemic poverty is somewhat puzzling.

Of course aggregate statistics, however compelling, do not adequately capture India's economic realities. Other evidence helps provide a different view of India's economic future. For example, one of India's largest industrial conglomerates, Tata, is on the verge of producing the world's cheapest car, the Nano, which is expected to be priced at $\$ 2,500$ and will meet the latest European emission standards. 
Parts of India are emerging as manufacturing hubs for major automotive firms, especially Hyundai.

Moreover, India's economic success is hardly confined to the industrial sector. The country's information technology sector continues to boom despite the current global economic downturn. According to the National Association of Software and Services Companies (the apex organization of Indian information technology businesses), growth in India's information technology sector has been staggering over recent years. In 1998 the sector accounted for 1.2 percent of India's GDP. By 2007, this figure had reached 5.2 percent. The same organization predicts that the information technology sector, and related areas in business-process outsourcing, will contribute as much as $\$ 64$ billion to India's economy in 2008.

The success of India's information technology sector and its business-process outsourcing is not an entirely unknown phenomenon to many Americans. Indeed, this very success became fodder for populist outrage during the 2004 presidential election when, for the first time, white collar industries were seeing jobs transferred to India and elsewhere from the United States. But not as well known is India's continuing success in the pharmaceutical industry. In this sector, which initially focused on the production of cheap generic drugs, some of the most successful players are now investing in developing new drugs and are attracting the attention of foreign drug makers. In June of this year, for instance, India's largest pharmaceutical company, Ranbaxy, sold a 70 percent stake in its equity to a Japanese firm, Daiichi Sankyo, for $\$ 4.6$ billion.

India's economic situation, in short, is complex and varied. The economy features sustained general growth and innumerable success stories. Even so, there is no denying that compelling economic challenges still plague the nation. The evidence from India and elsewhere shows that posting high rates of economic growth and boasting highly successful economic sectors will not alone result in the reduction of endemic poverty. To make significant strides in poverty reduction, India will need to go beyond market-oriented growth strategies and devise imaginative public policies.

There are no panaceas for poverty. As argued by, among others, Amartya Sen, the Indian No- bel laureate, the country must invest more in primary education and health care. Yet increased spending alone will not improve the lot of India's poor. Currently, India spends 3 percent of GDP on education. However, for complex reasons, a disproportionate segment of this expenditure is directed toward higher education. Hence the quality of primary schooling in India remains quite uneven. Some of India's states-especially Kerala, Tamil Nadu, and Himachal Pradeshhave made primary education a priority, with impressive results. But a large number of other states have grossly neglected their public schools, with disastrous consequences.

India spends close to 6 percent of its GDP on health care, but its public hospitals for the most part are in shambles. There is little or no oversight of public hospitals and maladministration is rampant. The country's wealthy, of course, have opted out of the public health care system and enjoy standards of health care comparable to those in the advanced industrial states.

India, however, cannot emerge as a great power with mere enclaves of excellence amid vast swaths of grinding poverty, economic disparity, and social inequality. These internal cleavages invariably will contribute to political instability and thereby hobble India's ambitions for major power status.

\section{DISHARMONY RULES}

To a considerable degree, the economic hurdles that confront India result directly from the country's fractious and increasingly coarse politics. The political spectrum in India ranges from two Communist parties- the Communist Party of India and the Communist Party of India (Marxist) which steadfastly refuse to countenance marketoriented reforms at the national level, to parties that remain committed to such reforms, such as the middle-of-the road Congress and the right-ofcenter Bharatiya Janata Party (BJP).

The width of the political spectrum and the virtual absence of one-party dominance in India's parliament for over two decades have meant that the forging of a political consensus on many issues of national significance can easily be held hostage to either parochial political or rigidly ideological concerns. Such a situation confronted the Indian polity in July this year when the 
Communists and their allies in the parliament withdrew support for the Congress-led regime of Prime Minister Manmohan Singh over the government's pursuit of a major civilian nuclear agreement with the United States.

This agreement, which will allow India to participate in normal global nuclear commerce, won the approval of the 45-nation Nuclear Suppliers Group in September. The US Congress granted its imprimatur to the deal on October 1. India until now has been excluded from nuclear energy commerce because of its unwillingness to sign the Nuclear Nonproliferation Treaty and because of its pursuit of nuclear weapons outside the ambit of the global nonproliferation regime. Under the terms of the pact, India has agreed to separate its nuclear establishment into two segments. Fourteen of its existing power reactors will be brought under International Atomic Energy Agency safeguards while another eight, presumably connected to India's nuclear weapons program, will remain off limits. Over time, the agreement should make a meaningful contribution to meeting India's burgeoning energy needs while reducing the country's acute dependence on imported petroleum products and fossil fuels.

The Communists and their allies opposed the agreement strictly on ideological grounds. Indeed, one prominent Communist leader, Prakash Karat, made no secret of the fact that his hostility toward the deal was based on his belief that it would contribute to greater Indo-US diplomatic amity. The BJP, for its part, displayed political opportunism in its crassest form. When in power in the early part of this decade, the party was instrumental in dramatically improving relations with the United States and had even initiated preliminary negotiations on the civilian nuclear agreement. However, when Prime Minister Singh decided to send the carefully negotiated agreement to the Nuclear Suppliers Group for its approval, the Communists, a group of small parties allied with them, and the BJP chose to attack the deal with vigor in the hope of bringing the government down and hastening new national elections.

In the end, though the government was hit with unproven, scurrilous allegations of bribing key parliamentary supporters during negotiations over the pact (though some overt political horsetrading certainly occurred), the Singh administration prevailed. It did not lose its parliamentary majority, and it managed to send the agreement off to the Nuclear Suppliers Group.
Nevertheless, the episode again underscored the ideological rigidity and political crassness that have come to characterize Indian politics. The outrageous behavior of parties at the two extremes of the political spectrum showed that even those well-schooled in the craft of parliamentary democracy were willing to violate one of its most fundamental and cherished tenets, the principle of loyal opposition. And this is not the first occasion when the BJP has resorted to such crude parliamentary tactics. Shortly after its electoral defeat in the national elections of 2004, the leadership of the BJP often resorted to obstreperous behavior to impede routine parliamentary proceedings.

These sorts of political tactics, aggravating India's ideological, regional, and personal divides, represent a serious impediment to the forging of a consensus on policies that would promote and sustain economic growth while also aiming at poverty reduction.

\section{STUBBORN INSURGENCIES}

Tragically, as the Singh government focused its energies on fending off the BJP's attacks and the Communists' attempts to unseat it over the nuclear deal, long-simmering discontent within the majority Muslim population in the disputed state of Jammu and Kashmir flared up once again in July. The Indian-controlled portion of this state has been the site of an ethno-religious insurgency since 1989. The insurgency had its origins in the exigencies of domestic Indian politics. However, once the insurgency erupted, significant Pakistani support for and involvement in it expanded its scope and increased its duration. In recent years, an Indian counterinsurgency strategy combining fierce repression with political concessions had managed to restore a large degree of normalcy. Nevertheless, a reservoir of disaffection from the Indian state remained in the region.

The immediate precipitant of this summer's crisis was a decision by the coalition government in the state to hand over some 100 acres of publicly owned land to the Shri Amarnath Shrine Board, a quasi-public body that oversees annual Hindu pilgrimages to a prominent Himalayan shrine. Once the government had announced its decision to build shelters for the Hindu pilgrims on the land, Syed Ali Shah Geelani, a local Islamist leader with pronounced pro-Pakistani sentiments, mobilized his followers, claiming that the decision to hand over the land was part of an unfolding and sinister plot to settle Hindus in the region. 
The Islamist's claims were entirely mendacious. However, his inflammatory rhetoric fired the popular imagination of young Kashmiris who harbor considerable resentment against the Indian state for the dislocations they have experienced during the insurgency of the past two decades. Soon public demonstrations started to rock the Kashmir valley. Faced with this apparent groundswell of discontent, one of the partners in the coalition regime, the Peoples' Democratic Party, abruptly withdrew its support for the land transfer. But the Congress Party refused to go along to take the same step.

In late July the regional government collapsed. India's central government took over the affairs of the state, also replacing the governor. The new governor, a highly respected former bureaucrat, Narendra Nath Vohra, in an attempt to assuage the feelings of the aggrieved Muslim population, rescinded the land transfer. His decision, however, led Hindu chauvinists in Jammu, the southern part of the state, to start a violent agitation. As matters threatened to spin completely out of control, the central government intervened again and sought to address the grievances of both constituencies. Negotiations proved successful in containing the agitation in Jammu, but violent demonstrations persisted in the Kashmir valley.

Unfortunately, the renewed agitation and very possibly a recrudescence of the insurgency in Kashmir are not the only challenges to authority that face the Indian state today. At least two other sources of violent discontent stalk the land. The first is a resurgence of the Naxalite movement. This movement had its origins among a group of neophyte Maoist guerrillas in the state of West Bengal in the late 1960s. They had started their violent agitation in the village of Naxalbari, from which the movement derives its name. By the early 1970s, largely through a strategy of harsh repression, the Indian state had managed to effectively suppress the movement.

To the dismay and shock of India's policy makers, the Naxalite menace has seen a dramatic resurgence. In 2006 as many as 165 districts in 14 states were facing periodic attacks from Naxalite guerrillas. The central government, while it has recognized the problem, has yet to devise a coordinated strategy to deal with this renewed threat to public order and wellbeing. To a large extent, India's federal structure hobbles the development of a uniform, nationwide strategy to tackle this problem. Unless law and order break down almost completely, the central government cannot intervene in the day-to-day law-and-order problems of particular states. Nor can the central government send in paramilitary forces without the express invitation and consent of state governments.

Moreover, the attempts by some states to confront the problem have actually worsened matters. In the state of Chhattisgarh, for example, authorities have created a village-based vigilante organization, the Salwa Judum (literally "peace mission"). This entity-composed of villagers armed with crude weaponry and lacking in training, organization, and control-has engaged in mayhem while attempting to counter the Naxalites. In the process, far from containing the Naxalite threat, the Salwa Judum may have contributed to the swelling of the rebels' ranks.

What explains the seemingly abrupt resurgence of this movement? There are no clear-cut answers. Popular accounts tend to emphasize the growing impact of India's fitful embrace of a more marketoriented economic development strategy and the concomitant inequalities that it has helped generate. This argument, though seemingly persuasive, is not entirely satisfactory because substantial economic inequity has been a constant of the Indian socioeconomic landscape since independence. Even so, economic disparities-combined with growing awareness of them and mobilization based on those grievances-certainly help to explain the return of the Naxalites. The sources of this malady in any case need to be carefully identified as India's central government and constituent states seek to devise strategies to contain and suppress it.

\section{HOMEGROWN TERRORISTS}

The other critical security threat confronting the Indian state is the rise of homegrown Islamic extremism. The sources of this threat are complex but more readily explicable than the Naxalite menace. During this past year, India has faced a spate of bombings in major cities including Jaipur in May and Ahmedabad in July. A little-known organization, the Indian Mujahideen-widely believed to be linked with the banned Students Islamic Movement of Indiahas claimed responsibility for some of these bomb attacks. A series of five coordinated bombings in New Delhi on September 13, 2008, represented perhaps the most daring and brazen of these attacks, even though the loss of life was not as great as in previous bombings. 
Muslims, who constitute India's largest minority, do not amount to a cultural or social monolith. Social class, sect, language, and regional affiliations divide them. However, the rise of a form of Hindu jingoism has contributed to a sense of siege among the Muslim community at large. Worse still, a pogrom against various Muslim communities in the western state of Gujarat in 2002, and a failure to prosecute its perpetrators, helped to radicalize a segment of young Muslim men.

Indian intelligence organizations now claim that many of these disaffected men have been trained in Bangladesh and Pakistan to carry out acts of mayhem, sabotage, and terror in India. It is impossible to confirm the veracity of these claims. However, circumstantial evidence does suggest that such external involvement in and support for terrorism is not beyond the realm of possibility. Bangladesh and especially Pakistan both have a record of supporting various dissident and insurgent movements in India.

As a consequence of the rise of a virulent Hindu nationalist movement since the 1980s, Muslim communities across India have been the objects of both increased opprobrium and violence. Worse still, a government-commissioned analysis of the status of Muslims in India, the Justice Rajinder Sachar Commission Report of 2006, provides a disturbing portrait of the Muslim community's poor representation in the realm of government employment. For example, even though Muslims comprise about 13 percent of India's population, a mere 3 percent can be found in the elite Indian administrative service, 1.8 percent in the exclusive Indian foreign service, and 4 percent in the powerful Indian police service.

Significantly lower educational attainments among Muslims as a whole explain, in considerable part, their failure to enter these critical governmental bodies. But how the Indian state seeks to redress these significant disparities in the years ahead will in large measure shape the evolution of the Muslim community's ties and loyalties to the Indian state. In turn, influential and successful members of the Muslim community must also suggest possible strategies for addressing the community's needs, for promoting social and cultural reform, and for eschewing violence. An absence of such leadership will inevitably provide politi- cal fodder to Hindu zealots who whip up populist hatred against Muslims.

\section{A FRAUGHT RELATIONSHIP}

In addition to the domestic troubles stemming from economic inequity, political squabbling, and ethno-religious tensions, India faces a very serious challenge in its relations with an increasingly unstable neighbor, Pakistan. Despite Pakistan's tenuous transition to democracy in February of this year, the problems accumulated from years of authoritarian misrule and chicanery still plague the country. Most importantly, despite the resignation of General Pervez Musharraf from the presidency in August, the military in Pakistan remains primus inter pares. It is far from clear that President Asif Ali Zardari and the minority regime of the Pakistan People's Party in parliament will be able to curb drastically the substantial powers of the military establishment any time soon.

And as long as the Pakistani military remains an important force in the country's political order, it will be exceedingly difficult for any civilian regime to improve relations with India. This was amply demonstrated in July when members of the reconstituted Taliban carried out a suicide bomb attack on the Indian embassy in Kabul, Afghanistan. Despite official denials from Pakistan, both India and the United States have publicly implicated Pakistan's powerful Inter-Services Intelligence Directorate in planning and masterminding this attack. Not surprisingly, the fitful bilateral peace process between India and Pakistan, the so-called "composite dialogue" that began in 2004, is now in considerable jeopardy.

Given Pakistan's present internal political disarray, the recent upheaval in Indian-controlled Kashmir, and the upcoming elections in India next year, it is most unlikely that any tangible progress will be made soon in Indo-Pakistani relations. Even if another meeting within the framework of the composite dialogue is held this year, the ensuing discussions will be little more than perfunctory.

\section{OVER THE HORIZON}

The Singh regime's inability to forestall the dramatic bomb blasts in Jaipur, Ahmedabad, and New Delhi; its slow and clumsy response to the widespread disturbances in Jammu and Kashmir; 
its failure swiftly to contain spiraling inflation: All this in combination with the anti-incumbency propensities of the Indian voter bodes ill for the present government in the national elections due in 2009. Unless in the next several months the administration can start addressing critical questions of both internal security and economic stability, its future in the next elections is virtually foreordained. Some Indian political analysts are already predicting the demise of the Singh regime based on its failure to prevent the multiple bombings in the nation's capital.

In any case, it is easy to anticipate how the principal opposition party, the BJP, will campaign. It will unfailingly exploit the present administration's very real shortcomings and insist that it will tackle India's challenges with more alacrity and efficacy. And the BJP is not the only bête noire that the Congress Party faces in the next elections. In the large, poor, populous state of Uttar Pradesh, the current lower-caste chief minister, Kumari Mayawati, has already made clear her national ambitions. Whether she will be able to mobilize significant support beyond her political base in her home state and northern India remains an open question.

More to the point, even if she and her Bahujan Samaj Party were to win a substantial number of parliamentary seats, they would still have to forge a coalition with other political parties to form a government. Such a regime would inevitably prove unstable, as regional, ideological, and personal differences would soon come to the fore and threaten any coalition. While India has had some experience with coalition governments, none has been known for its longevity or stability.

As the year nears its end, the Indian polity, though not facing any threat to its viability, nevertheless confronts a range of domestic and external challenges that will severely tax the resources of the next regime in office. So long as India remains weighed down by its various burdens-and lacks a national consensus on critical policies pertaining to economic growth, poverty alleviation, secularism, and relations with contentious neighbors-it inevitably will fail to realize its potential for great power status. 